\title{
Plasma spraying of hydroxyapatite coatings using powder, suspension and solution feedstocks
}

\author{
Natryskiwanie plazmowe powłok hydroksyapatytu \\ z wykorzystaniem proszku, zawiesiny oraz roztworu
}

\section{Abstract}

The possibility of producing nano-sized coatings by thermal spray processes seems to be very interesting for many industrial applications. Due to the small size of the grains, it is possible to achieve the properties which are not observed in the micrometric scale on the same kind of material. The aim of the current work is to present the alternative methods for conventional powder plasma spraying (APS) which is well known technology for deposition of micron-sized coatings using powder feedstock. Two plasma spraying processes with liquid feedstock were used - suspension plasma spraying (SPS) and solution precursor plasma spraying (SPPS) using aqueous solution directly from wet chemical precipitation process. All experiments were performed based on hydroxyapatite, which is a very important material for biomedical applications. Coatings were produced by three mentioned methods but the deposition process was realized using only one spray set-up equipped with SG-100 plasma torch. Short background of the three different processes performed followed by a short description of liquid feedstock preparation is presented. Microstructure investigation and phase composition analysis of the prepared coatings were carefully characterized using scanning electron microscopy (SEM) and $\mathrm{X}$-ray diffraction (XRD) respectively. Finally, the analysis and comparison of coatings deposited by different plasma spray processes were discussed.

Keywords: Atmospheric Plasma Spraying, Suspension Plasma Spraying, Solution Precursor Plasma Spraying, Hydroxyapatite

\section{Streszczenie}

Możliwość wytwarzania powłok o budowie nanometrycznej wydaje się być bardzo interesująca pod kątem ich zastosowania w wielu gałęziach przemysłu. Dzięki bardzo drobnoziarnistej strukturze możliwe jest osiągnięcie właściwości powłok, które nie są możliwe do zaobserwowania w tych samych materiałach lecz w skali mikro. Celem niniejszej pracy jest przedstawienie alternatywnych metod dla konwencjonalnego natryskiwania plazmowego (APS), które jest dobrze poznanym procesem wytwarzania powłok charakteryzująch się budową mikrometryczną. Zaprezentowano dwa nowe procesy natryskiwania plazmowego z fazy ciekłej - natryskiwanie plazmowe zawieisn (SPS) oraz natryskiwanie plazmowe roztworów (SPPS). Wszystkie eksperymenty przeprowadzono z wykorzystaniem hydroksyapatytu, który jest bardzo istotnym materiałem dla zastosowań biomedycznych. Powłoki zostały wytworzone z użyciem trzech wymienionych technologii, jednak proces natryskiwania realizowany był za pomocą jednego stanowiska wyposażonego w palnik plazmowy SG-100. W pracy przedstawiono zarys teoretyczny wykorzystanych metod natryskiwaniawrazzopisem proceduryprzygotowaniamateriału wejściowego (proszku, zawiesiny oraz roztworu). Następnie przedstawiono badania mikrostruktury i analizę składu fazowego przygotowanych powłok, które zostały wykonane z wykorzystaniem skaningowej mikroskopii elektronowej (SEM) i dyfrakcji promieni rentgenowskich (XRD). Przeprowadzono również analizę i porównanie powłok wykonanych z użyciem różnych procesów natryskiwania plazmowego.

Słowa kluczowe: natrsykiwanie plazmowe proszkowe (APS), natryskiwanie plazmowe zawiesin (SPS), natryskiwanie plazmowe roztworów (SPPS), hydroksyapatyt

\section{Introduction}

Thermal spraying [1] is a technology of depositing coatings by means of introducing feedstock into a flame or plasma jet propelled onto the surface of a prepared substrate.
The feedstock materials is melted or only heated during transportation towards substrate and when subsequent particles hit the substrate the coating, growth is possible layer by layer. Thermal spraying can be categorized according to the energy source used, that is, chemical energy source and electrical energy source. Powder flame spraying, high velocity

M. Sc. Eng. Rolando T. Candidato Jr, Prof. Dr. Eng. Lech Pawłowski, Prof. Dr. Eng. Alain Denoirjean - SPCTS, University of Limoges, France; M. Sc. Eng. Paweł Sokołowski, Dr. Eng. Leszek Łatka, Dr. Eng. Stefan Kozerski - Faculty of Mechanics, Wrocław University of Technology 
oxygen fuel spraying and detonation thermal spraying are examples of the chemical energy sources while for electrical supplied thermal spray are wire arc spraying and plasma spraying.

Among the mentioned methods above, plasma spray process [2] is the most versatile one as it is capable of spraying all materials having a melting point and, after some powder preparation also the ones which do not have liquid phase (graphite) and those which soften with temperature (glass and polymers). Moreover, plasma spraying is commonly used and is standard method in producing coatings for biomedical purposes [3] and aside from this, many works have been conducted using plasma spraying for different industrial applications like in aerospace, power generation,

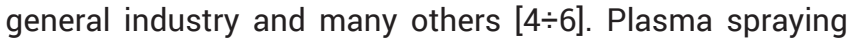
can be categorized as atmospheric plasma spray (APS) and vacuum plasma spray (VPS) [7]. Atmospheric plasma spray is more advantageous owing to its high coating adhesion strength and high deposition rate that can be used in diverse applications. The conventional powder spraying (APS) [8] uses coarse powders that result to coatings with micrometer structural features. The great research interest for obtaining nanometric or sub-micron scale coatings is due to enhanced properties compared to micrometer-sized coating's features. Aside from this, the nanometer-sized coatings have improved strength and toughness. Because of this, many attempts to spray nanometric powders as feedstock to obtain coating with nanometric features were conducted. However, the difficulty of injecting nanometric powders in the core of high enthalpy flow plasma is one of the major problems; thus, it is not possible to obtain very fine grained coatings using conventional APS method [9].

The solution of this problem was presented few years ago (in 1997) by the group of researchers from Sherbrook University in Canada. The first idea assumed the realization of coatings by means of suspension plasma spray (SPS)

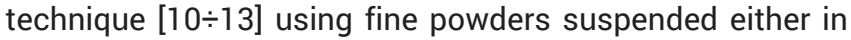
alcohol or water medium. The proper preparation of the liquid based precursor was to provide the protection against the high temperature in plasma and allowed transport of fine powder particle by the plasma jet. But the tedious powder preparation and suspension stabilization are some drawbacks of SPS process. Interestingly, another method for the deposition of nanometric coatings called solution precursor plasma spraying (SPPS) was also proposed. SPPS is more versatile method in where solution precursor (liquid) is used instead of the powder-based feedstock [14:16].

These novel plasma processes using liquid feedstock are being tested for the deposition of hydroxyapatite (HA) $[17,18]$. Hydroxyapatite [19] which is the main inorganic component of human bone having 1.67 stoichiometric ratio of $\mathrm{Ca}$ to $\mathrm{P}$ is particularly studied among other calcium phosphates because it has good biocompatibility, osteoconductivity and has better biological response to the physiological environment which finds its potential in bio-medical applications. Aside from these, there are many works $[20,21]$ also on the wet chemical precipitation using different precursors of HAp, thus this process can be exploited to explore its potential for plasma spraying.

\section{Theoretical background of plasma spray processes}

Conventional plasma spraying using powder feedstock (APS) is already an established technology for deposition of thick coatings for various applications with high deposition rate. This method bases mostly on the commercial powders and does not require any additional precursor preparation.
The micrometric-sized powder particles are feed into the plasma jet in which they are melted and propelled to the substrate forming a dense coating composed of large splats and cracks which are observed as lamellar structures across the section (Fig.1) [22]. The formation of micro-cracks which are parallel to the substrate is undesirable since this causes surface failure of the coating. Because of this disadvantage of APS, plasma spraying using liquid feedstock [23] has been innovated to obtain fine structures of the coatings.

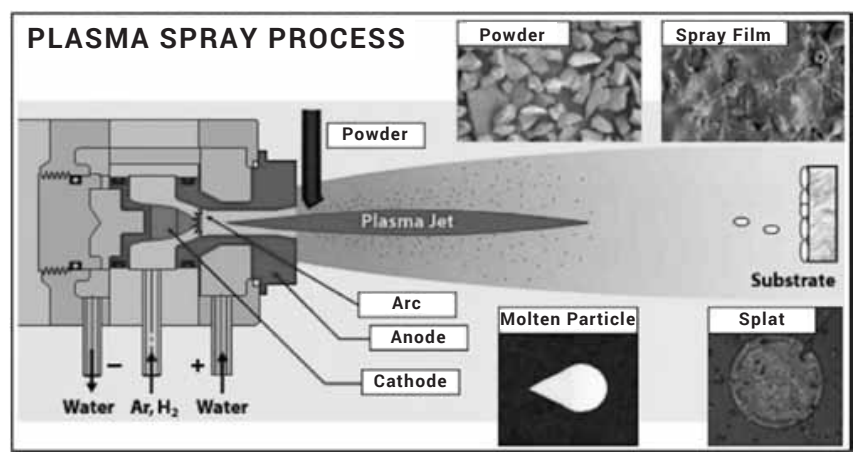

Fig. 1. The background of Atmospheric Plasma Spraying process [23] Rys. 1. Podstawy konwencjonalnego procesu natryskiwania plazmowego APS [23]

Currently, suspension plasma spraying (SPS) is employed for deposition of finely graded coatings like hydroxyapatite [24] using ball milled commercial powders mixed with water, ethanol or a mixture of this to form a suspension. Technology of suspension is part of chemistry of colloids. Formulation of suspension is not only limited to mix liquid solvent with fine particles of spraying material. These systems also contain additional components (such as dispersing and stabilizing agents), which minimize processes of agglomeration and sedimentation of fine particles and improve the rheological properties of suspension (so called suspension stabilization). One way to obtain fine particles is milling of coarse powder. Size distribution of milled particles depends on many parameters, mostly on milling time and energy of milling. The optimization of these parameters is realized by:(i)rotation velocity of milling device, (ii) the balls quantity and balls diameter, as well as by (iii) a mass ratio between balls and powder [25]. The solid phase is put in the liquid solvent, which is usually water, alcohol (ethanol, isopropanol) or their mixture. Depending on kind of solvent, different interactions with jet or flame take place. Water cools down jet, whereas alcohol on the contrary, heats it up. On the other hand, minimal velocity, which enables penetration into plasma jet is lower in case of water based suspension than alcohol ones [26]. Another component which is added to the suspension is dispersant. This is generally a surface active agent which is absorbed on the particle surface preventing the agglomeration of the particles and keeping suspension well dispersed [27]. The stabilization is characterized by zeta potential. The potential is defined as an electric potential difference between the particle surface and the liquid beyond the charge cloud of ions [28]. The suspension is stable if the potential is outside the limits of $+30 \mathrm{mV}$ or $-30 \mathrm{mV}$ [29]. Stability of suspensions is resultant of attraction forces sum (van der Waals) and repulsion ones (electrostatic), which influence the movement of powder particles in suspension. Viscosity is also a determining factor that characterized suspension. This parameter determines facility of suspension to be pumped and transported through a pipeline. The viscosity of stable suspension is lower than that of unstable one and it increases with the fraction of solid phase. At the same time pumping is easier if the viscosity is lower [25]. The rheological properties 
of the suspension are strongly influenced not only by the solid content, but also by the type of the powder (particle size and surface chemistry) and the type of the solvent and dispersant agent [30].

Works regarding SPS reported that the following mechanism occurred during spraying: (a) aerodynamic break-up, (b) solvent evaporation, (c) sintering of fine solids, (d) melting of the sintered fines solids and sintered agglomerates, (e) evaporation of liquid material and (f) impacting of melt to the substrate (Fig. 2)[26,31]. Although SPS has been successfully applied for various types of materials for desired application, the major drawbacks of this method are the long process of powder preparation and the stabilization of suspension.

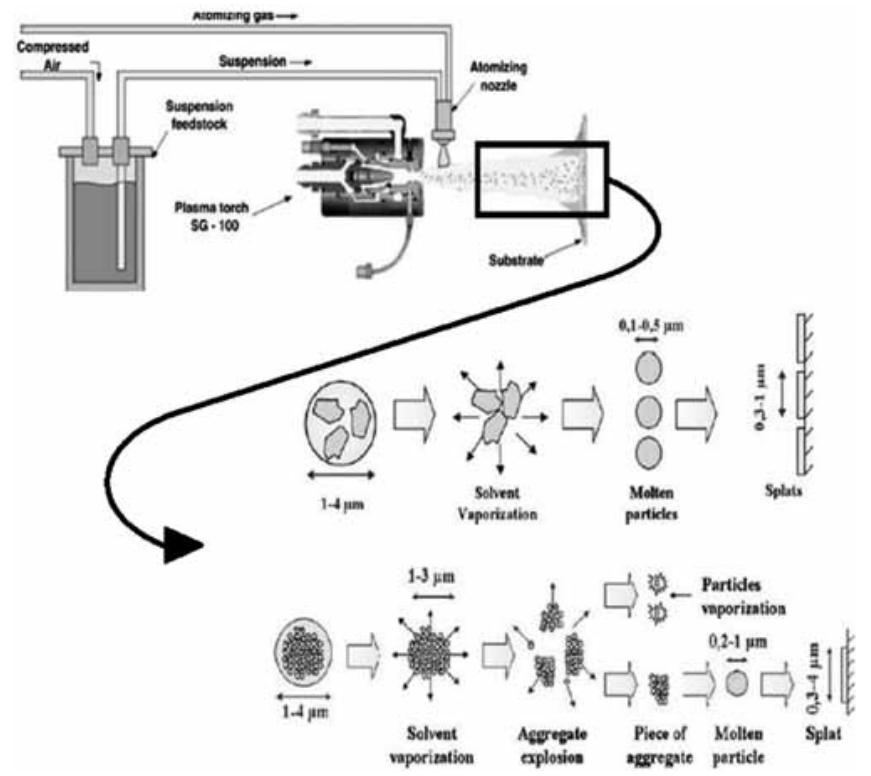

Fig. 2. Phenomena occurring during Suspension Plasma Spraying process [26,31]

Rys. 2. Zjawiska mające miejsce $w$ trakcie procesu natryskiwania plazmowego zawiesin $[26,31]$

On the other hand, plasma spraying using solution precursors (SPPS) has recently attracted much attention due to its promising coating features and properties. In this method small particles of powder are completely replaced by droplets of liquid. The general idea of the precursor preparation is to create desired stoichiometry of the compounds which mostly are different salts, nitrates and acetates with the addition of solvent such as water or ethanol. In SPPS, ionic or colloidal solutions are often used. The former uses ionic salts dissolved in a solvent in where the solvent molecules break the bonds of the salt and surround each ion forming a hydration shell while the latter is a homogeneous dispersion of chemical network having size in nanometer scale. The stability of solution is ensured by the Brownian motion of the medium molecules as well as electrostatic or steric effects avoiding agglomeration caused by the van der Waals forces [32]. One big advantage of SPPS compared to SPS is the molecular level of mixing of the liquid precursors allowing the formation of stoichiometric oxides as well as creating more avenues for developing functional oxide coatings having complex structures.

During the spray process, when the precursor enters the plasma jet different phenomena can occur. (i) aerodynamic fragmentation of the droplets, (ii) partial evaporation of the liquid, (iii) condensation of the precursor and precipitation of particles or shells, (iv) rapid internal pressurization which may lead to shell rupture, (v) heating and melting/sintering of particles, (vi) partial evaporation of melt, (vii) contact of the particles with substrate and formation of the coatings
(Fig.3)[33]. Depending on the process and the precursor preparation, different particle morphologies can be observed in the coating microstructure including small solid particles, fragmented shells and splats. Therefore, the further diminution of grain size in the coating microstructure can occur. Another advantage of this method is the elimination of the powder feedstock preparation process.

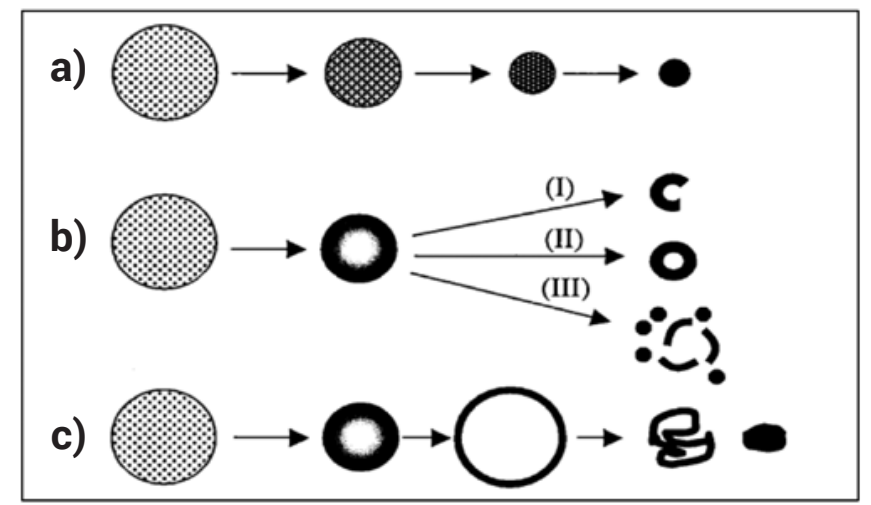

Fig. 3. Different possibilities of particle formation in Solution Precursor Plasma Spraying [33]

Rys. 3. Możliwe mechanizmy formowania cząsteczek w trakcie natryskiwania plazmowego roztworów [33]

\section{Experimental Procedure}

\section{Feedstock preparation}

The coatings were deposited using three different plasma spray processes, namely APS, SPS and SPPS, thus, preparation of feedstock material in three different forms was necessary. For APS process, commercial hydroxyapatite powder manufactured by TOMITA (Japan) was used. Fig.4 and Fig. 5 shows the morphology and X-ray diffractogram of the HA powder respectively.

For SPS process the HA powder was synthesized by wet method using following chemicals: (i) calcium nitrate, (ii) ammonium phosphate and (iii) ammonium hydroxide. All products were delivered by Arcos Organics. The complex procedure of HA powder production was described elsewhere $[13,34]$. Moreover the mechanical ball milling was also performed in order to reduce the size of this powder. After 3 hours of milling process, the size of powders was $\mathrm{dv}_{50}=5 \mu \mathrm{m}$. Fig. 6 shows the morphological structure of HA powder after ball milling while Fig. 7 presents the particle size distribution after the milling process. X-ray diffractogram of the milled powder is presented in Fig. 8 showing the peaks of crystalli-

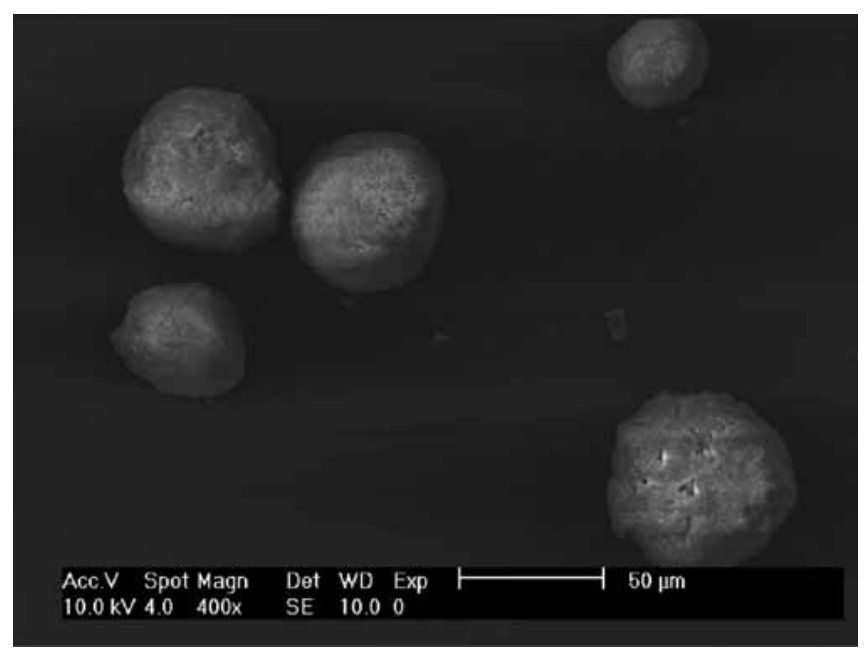

Fig. 4. Morphology of commercial HA powder used for APS Rys. 4. Morfologia komercyjnego proszku HA użytego w procesie APS 
ne hydroxyapatite. Using the milled powder, the suspension was formulated by taking c.a. $20 \%$ of solid phase (milled powder) and $80 \%$ of liquid phase. The solvent was a mixture of ethanol and distilled water (with the mass ratio 1:1). Before spraying the stability of suspension was specified by measuring of zeta potential. The analysis was made with a Zetamaster Malvern apparatus following standard procedure. The potential of tested suspension was equal to - 14.6 $\mathrm{mV}$ and is shown in Fig. 9.

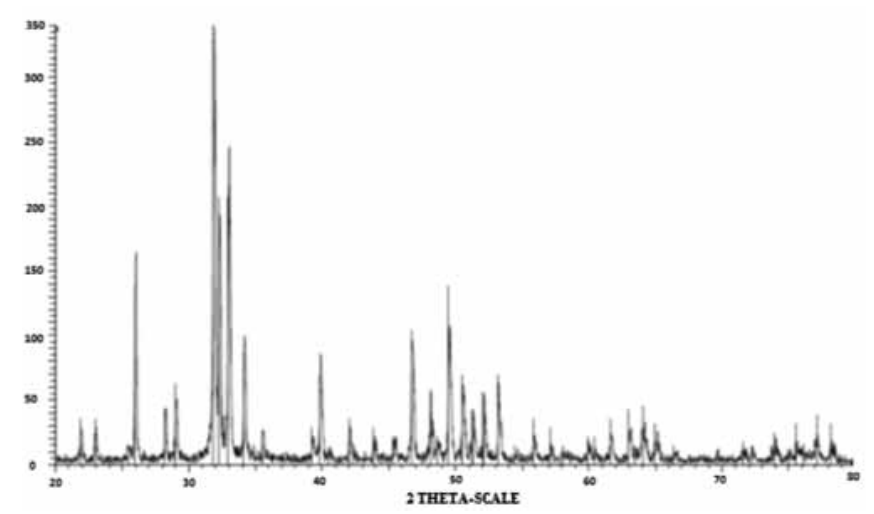

Fig. 5. X-ray diagram of the commercial powder indexed to standard powder diffraction file of HA (PDF 09-0432)

Rys. 5. Dyfraktogram komercyjnego proszku HA (opisany z użyciem PDF 09-0432 z bazy JCPDS)

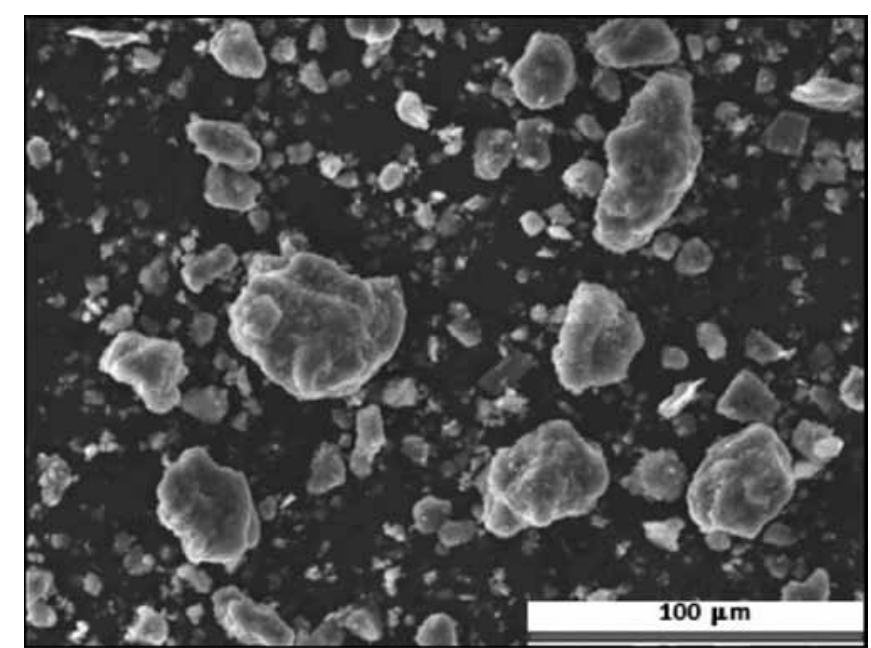

Fig. 6. Morphological structure of HA powder particles after ball milling

Rys. 6. Morfologia cząsteczek proszku HA poddanego procesowi mielenia kulowego

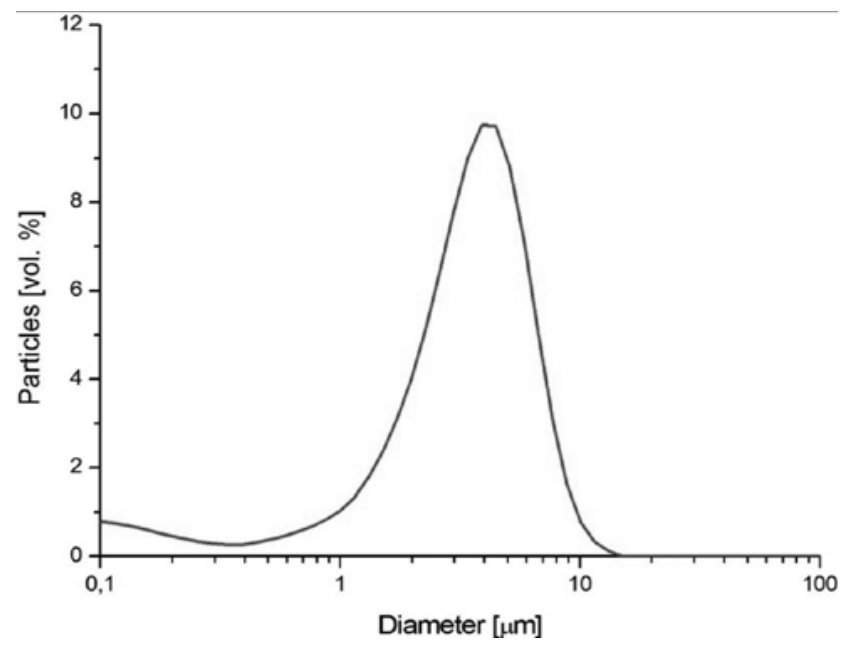

Fig. 7. Particle size distribution of ball milled HA powder Rys. 7. Rozkład wielkości cząsteczek mielonego proszku HA

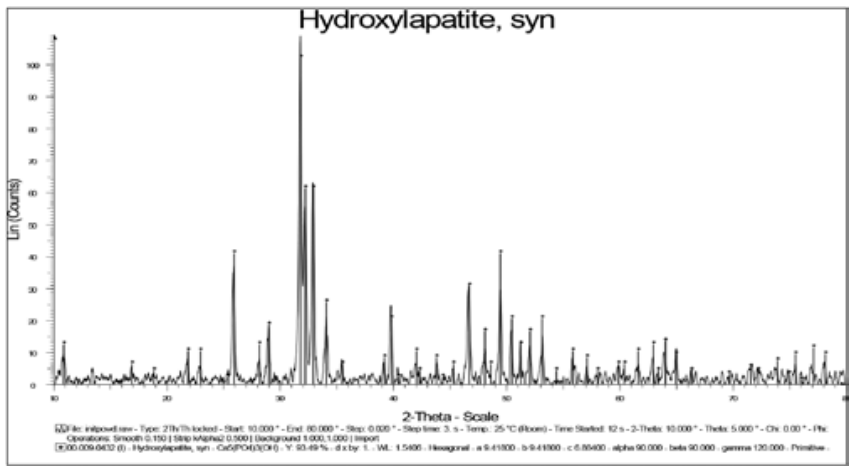

Fig. 8. Typical X-ray diagram of the powder indexed to standard powder diffraction file of HA (PDF 09-0432)

Rys. 8. Dyfraktogram mielonego proszku HA (opisany z użyciem pliku PDF 09-0432 z bazy JCPDS)

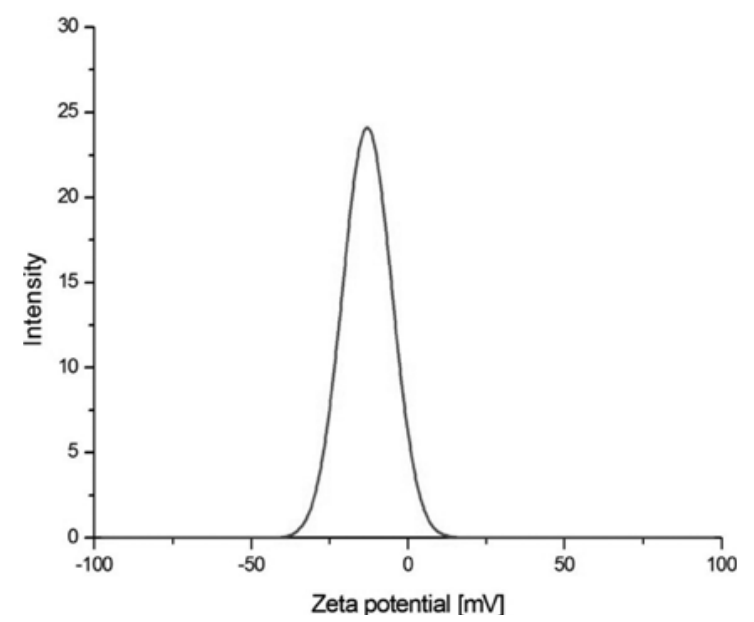

Fig. 9. Zeta potential of the suspension used in SPS

Rys. 9. Wyniki pomiaru potencjału Zeta zawiesiny na bazie proszku HA

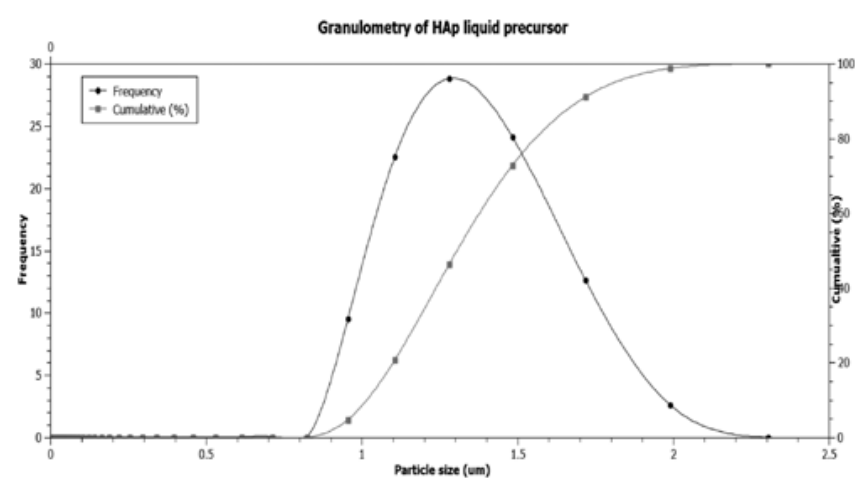

Fig. 10. Granulometry of the aqueous calcium-phosphate solution Rys. 10. Wyniki badań wielkości cząsteczek w roztworze fosforanu wapnia

For solution plasma spraying of HA, the calcium-phosphate solution as liquid feedstock was prepared by wet chemical precipitation method using aqueous solution of calcium hydroxide and ammonium phosphate. The ammonium phosphate aqueous solution was added dropwise into a calcium hydroxide solution and the mixture was magnetically stirred and heated at low bath temperature $\left(70^{\circ} \mathrm{C}\right)$ using a magnetic stirrer with hotplate apparatus. Formation of precipitates was observed during the course of stirring and these precipitates are believed to be already an amorphous HA. After constant stirring and heating, the calcium-phosphate solution was aged for at least 24 hours at and was directly fed to the plasma. Granulometry test was performed using a dynamic light particle size analyzer to determine the particle size of the precipitates found in the calcium phosphate solution. Standard procedure was followed and $\mathrm{NaOH}$ was used as a diluting medium in order not to alter the $\mathrm{pH}$ of the solution. Fig. 10 shows the size distribution of the solution having $\mathrm{dv}_{50}=1.3 \mathrm{um}$. 


\section{Description of the plasma spray process}

The deposition process was realized using plasma setup equipped with single cathode-single anode SG-100 torch (PRAXAIR, Minneapolis U.S.). The internal feedstock injection was used in all spray processes. Injectors with various diameters were used to keep appropriate feed rate of each material. A 5-axis industrial robot IRB-L6 of ABB (Zurich, Switzerland) was used to move plasma torch and scan the sample's surface. The samples were placed on the flat table which was connected to the vacuum pump necessary to keep substrates on the surface of the table. The measurement of temperature was realized each time using noncontact infrared thermometer. The test stand is presented in Fig.11. The deposition process parameters were optimized for each process separately and are collected in Table I.

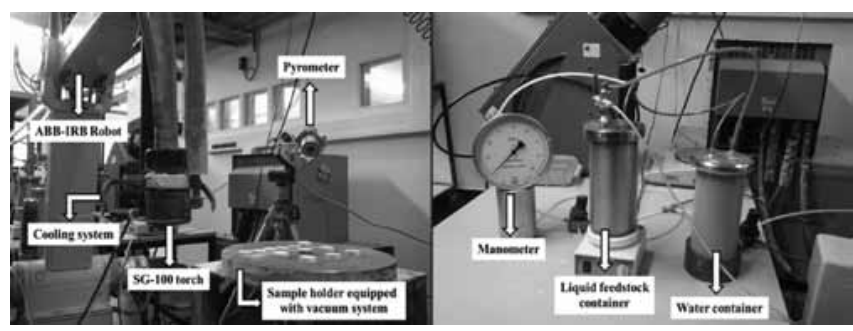

Fig. 11. Plasma spraying set-up used in the experiment Rys. 11. Stanowisko do natryskiwania plazmego

\section{Characterization of coatings}

Due to different mechanisms of coatings formation in APS, SPS and SPPS processes, the observation of coatings microstructure was the key issue in the current work. The coatings' morphology was characterized on the cross-section as well as on the samples surface using SEM microscopy (SEM, Philips XL30). X-ray diffraction (XRD) was also done to determine the phase composition of coatings using Bruker AXS apparatus type D8 with $\mathrm{Cu}$-Ka radiation. Collected diffractograms were analyzed using dedicated Diffrac+EVA Software equipped with JCPDS-ICDD database (International
Centre of Diffraction Data). The percentage of the crystalline phases present in coatings were determined from the reference intensity ratio (RIR) method described by Prevey [35], which uses the comparison of strongest peaks intensities.

\section{Results and Discussions}

\section{Characteristics of coatings}

The micrographs of coatings sprayed using conventional powder spraying (APS) can be observed on the Fig. 12. It can be noticed that large splats from fully melted particles are present together with partially melted particles along the surface of the coatings. Lamellar structures with the presence of micro-cracks can be seen at the cross-section of the coatings which is a characteristic of plasma spraying using powder feedstock. It is observed that these micro-cracks follow the splat boundaries. The formation of cracks may lead to a decrease in mechanical strength as well as increased dissolution rate of the coatings. Generally, a brick-wall type structure can be deduced at the cross section of the coatings produced by APS suggesting a coating build up parallel to the surface. The X-ray diffractogram of APS hydroxyapatite coatings is presented in Fig.13. It shows that HA was the major crystalline phase but phases like TCP's, TTCP and $\mathrm{CaO}$ were also present and are attributed to the decomposition of HA under the high plasma temperature.

On the other hand, Fig. 14 shows the micrographs of coatings sprayed using suspension plasma spraying process. On the surfaces of sprayed coating a characteristic "two-zones" microstructure is observed. It is built with well melted lamellas and between them there are sintered zones which include submicrometric and even nanometric scale grains. One of it, called "dense zone" and composed of large and well-molten lamellae, is dense and includes crystalline hydroxyapatite together with its decomposition products, such as tricalcium phosphate (TCP) and the phase rich in $\mathrm{CaO}$. Another one, called "sintered zone", is composed of small grains of initial hydroxyapatite similar to that of the solid

Table I. Details of the plasma spray parameters used in the experiment

Tablica I. Parametry procesów (APS, SPS oraz SPPS), które użyte zostały w celu wykonania powłok

\begin{tabular}{|c|c|c|c|}
\hline & APS & SPS & SPPS \\
\hline Working gas composition & $\mathrm{Ar}+\mathrm{H}_{2}$ & $\mathrm{Ar}+\mathrm{H}_{2}$ & $\mathrm{Ar}+\mathrm{H}_{2}$ \\
\hline Carrier gas & Argon (3.5 slpm) & - & - \\
\hline Power & $24 \mathrm{~kW}$ & $30 \mathrm{~kW}$ & $36 \mathrm{~kW}$ \\
\hline Spray distance & $100 \mathrm{~mm}$ & $60 \mathrm{~mm}$ & $80 \mathrm{~mm}$ \\
\hline Scan speed & $500 \mathrm{~mm} / \mathrm{s}$ & $500 \mathrm{~mm} / \mathrm{s}$ & $600 \mathrm{~mm} / \mathrm{s}$ \\
\hline Feedstock feedrate & $16 \mathrm{~g} / \mathrm{min}$ & $20 \mathrm{~g} / \mathrm{min}$ & $35 \mathrm{~mL} / \mathrm{min}$ \\
\hline Type of injection & $\begin{array}{c}\text { Nozzle inside torch, } \\
\text { (0.5 mm internal diameter) } \\
\text { oriented at } 90 \text { o relative to the } \\
\text { plasma jet (radial) }\end{array}$ & $\begin{array}{c}\text { Nozzle inside torch, } \\
(0.3 \mathrm{~mm} \text { internal diameter; } \\
\text { continuous stream of HAp } \\
\text { liquid precursor) oriented at } \\
90^{\circ} \text { relative to the plasma jet } \\
\text { (radial) }\end{array}$ & $\begin{array}{c}\text { Nozzle inside torch, } \\
\text { (0.3 mm internal diameter; } \\
\text { continuous stream of HAp } \\
\text { liquid precursor) oriented at } \\
90^{\circ} \text { relative to the plasma jet } \\
\text { (radial) }\end{array}$ \\
\hline Injection pressure & - & 0.5 bars & 0.5 bars \\
\hline Scan Pattern & $\begin{array}{l}\text { Rectangular patterns with } \\
\text { offset distance of } 5 \mathrm{~mm} \text { after } \\
\text { each torch run }\end{array}$ & $\begin{array}{l}\text { Rectangular patterns with } \\
\text { offset distance of } 3 \mathrm{~mm} \text { after } \\
\text { each torch run }\end{array}$ & $\begin{array}{l}\text { Rectangular patterns with } \\
\text { offset distance of } 3 \mathrm{~mm} \text { after } \\
\text { each torch run }\end{array}$ \\
\hline Substrate & $\begin{array}{l}\text { Stainless steel sand blasted } \\
\text { with alumina }\end{array}$ & $\begin{array}{l}\text { Stainless steel sand blasted } \\
\text { with alumina }\end{array}$ & $\begin{array}{l}\text { Stainless steel sand blasted } \\
\text { with alumina }\end{array}$ \\
\hline
\end{tabular}


used to formulate the suspension. The monomodal particle size distribution and spray parameters result in relative dense and quite homogenous coating obtained by SPS method.

The typical X-ray of sprayed coating by SPS is presented in Fig. 15. Characteristic peaks of HA and its decomposition phases such as TCP, TTCP and $\mathrm{CaO}$ were present. This is due to the high temperature experienced by the particle during the spraying process. Moreover, after calculations, the phase percentage on all of the HA coatings was estimated, results are collected in Table II.

Fig.16 meanwhile shows the SEM images of the coatings deposited using SPPS. Fine-grained microstructures, spherical particles, agglomerates and fragmented shells which are the characteristic microstructural features of plasma spraying using solution were observed at the surface of the coatings. Coating build-up is believed to be a combination of solid precipitates contained in a liquid (amorphous $\mathrm{HA}$ ) and pure liquid droplets which is purportedly to react in the plasma jet. Fragmented structures are due to liquid droplets that undergoes internal rupture after the solid shell formation. This process can be repeated and may produce fine spherical particles. Additionally, formation of spherical particles can be also due to the already formed solid precipitates in the calcium phosphate solution and the liquid around the solid undergoes evaporation before impact to substrate. The cross-section of the coatings is seen to have dense formation.

X-ray diffraction data of the HA coating sprayed using SPPS is presented in Fig. 17. Analysis of phases present in the coating revealed that $\mathrm{HA}$ is remarkably the major phase. Decomposition phases like TCP, TTCP and $\mathrm{CaO}$ were also taken into account and are due to the high temperature experience by the solution in the plasma flame. The presence of calcium carbonate was also detected and is ascribed

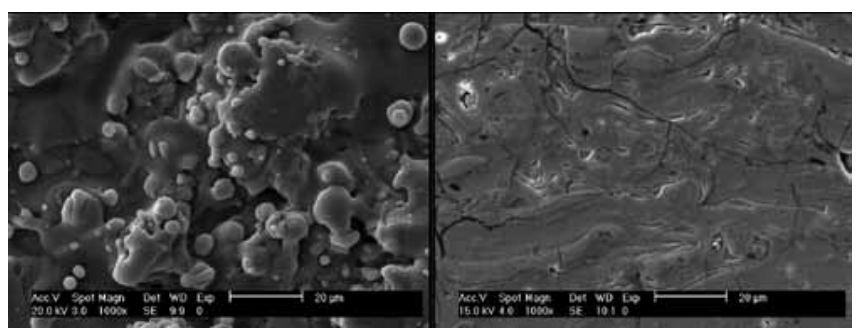

Fig. 12. SEM at the surface of the coating sprayed using APS process showing micron size splats and partially melted particles. Left is the surface image and right is the image at cross-section Rys. 12. Mikrostruktura powłok natryskiwanych plazmowo metodą APS. Po lewej obraz powierzchni pokazujący splaty o rozmiarze mikrometrycznym, po prawej przekrój poprzeczny powłoki (SEM)

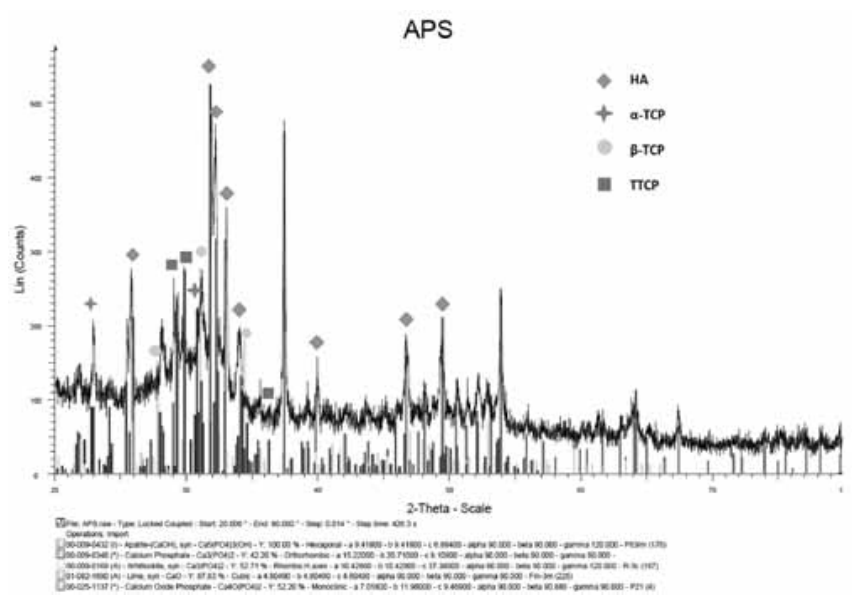

Fig. 13. XRD data of APS sprayed HA coatings showing peaks of HA Rys. 13. Badania XRD powłok wykonanych metodą APS z oznaczonymi pikami HA to the calcium-phosphate solution preparation in where calcium hydroxide may react to the carbon dioxide in the air since this was done not in a controlled environment but in the air atmosphere. It can be also due to the solution that interacts with air during spraying. Presence of impurities in the HA coating is unwanted since it affects the dissolution process of HA and an approach should be design to get rid of these impurities. A simple way is to conduct solution preparation in an inert atmosphere and maybe change solution precursors. The percentage in wt.\% of crystalline phases present in the coating is shown in Table II.

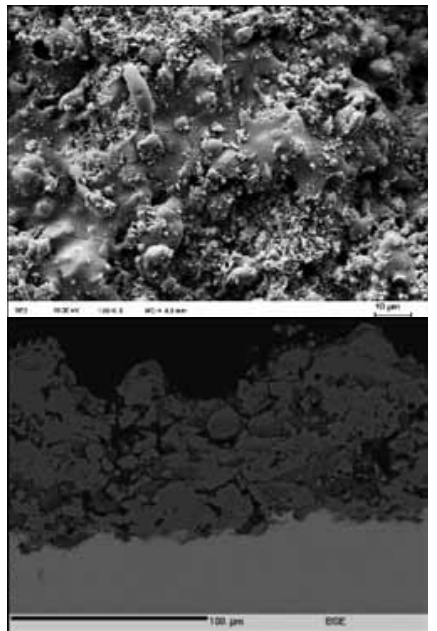

Fig. 14. SEM at the surface of the coatings sprayed using SPS process showing characteristic "two-zones" microstructure. Left is the surface image and right is the image at cross-section

Rys. 14. Zdjęcie SEM na powierzchni powłoki wykonanej metodą SPS ukazujące typową "dwustrefową" budowę (po lewej) oraz obraz przekroju poprzecznego powłoki

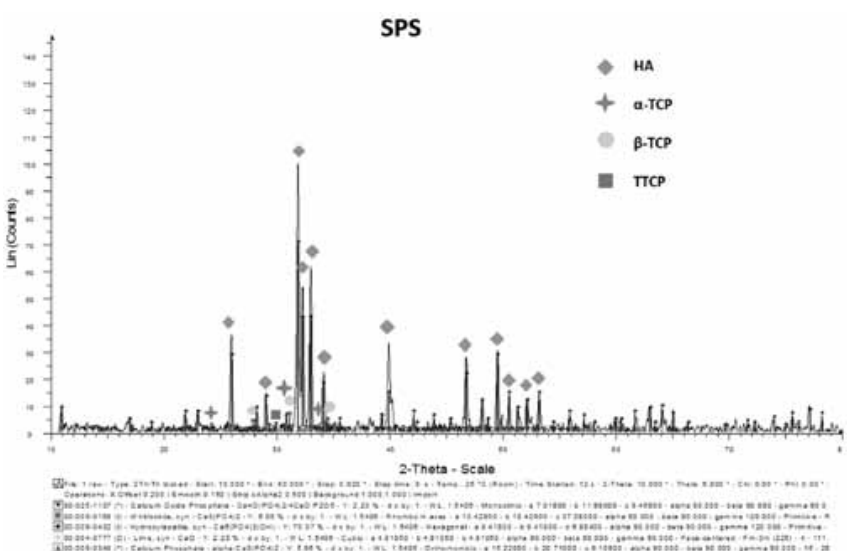

Fig. 15. X-ray diagram of the HA coating sprayed by SPS process (the characteristic phases of HA were marked separately) Rys. 15. Dyfraktogram powłoki HA wytworzonej metodą SPS z zaznaczonymi pikami HA

Table II. Phase percentage in the plasma sprayed HA coatings Tablica II. Skład fazowy powłok HA

\begin{tabular}{|c|c|c|c|}
\hline $\begin{array}{c}\text { Crystal } \\
\text { phases }\end{array}$ & APS (\%) & SPS (\%) & SPPS (\%) \\
\hline $\mathrm{HA}$ & 45.4 & 85.6 & 70.9 \\
\hline $\mathrm{a}-\mathrm{TCP}$ & 7.1 & 11.1 & 6.7 \\
\hline$\beta-\mathrm{TCP}$ & 16.1 & 2.4 & 8.9 \\
\hline $\mathrm{TTCP}$ & 22.9 & 0.1 & 8.5 \\
\hline $\mathrm{CaO}$ & 8.5 & 0.8 & 0.2 \\
\hline $\mathrm{CaCO}_{3}$ & - & - & 4.8 \\
\hline
\end{tabular}




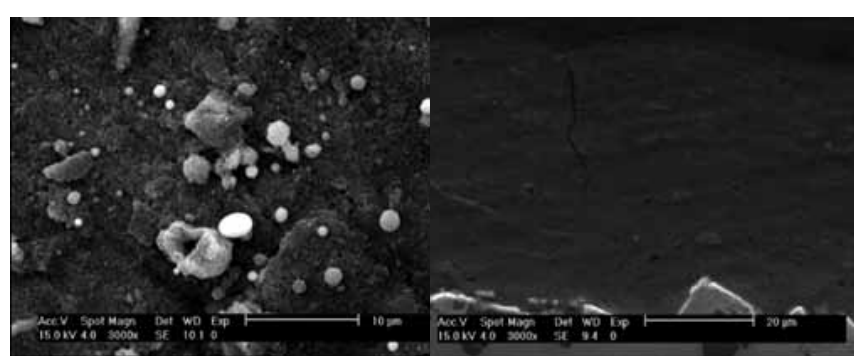

Fig. 16. SEM at the surface of the coating sprayed using SPPS process showing spherical particlesand agglomerated structures. Left is the surface image and right is the image at cross-section Rys. 16. Powierzchnia powłoki wykonanej metodą SPPS ukazująca sferyczne cząsteczki oraz liczne aglomeraty (po lewej) oraz przekrój poprzeczny powłoki (po prawej)

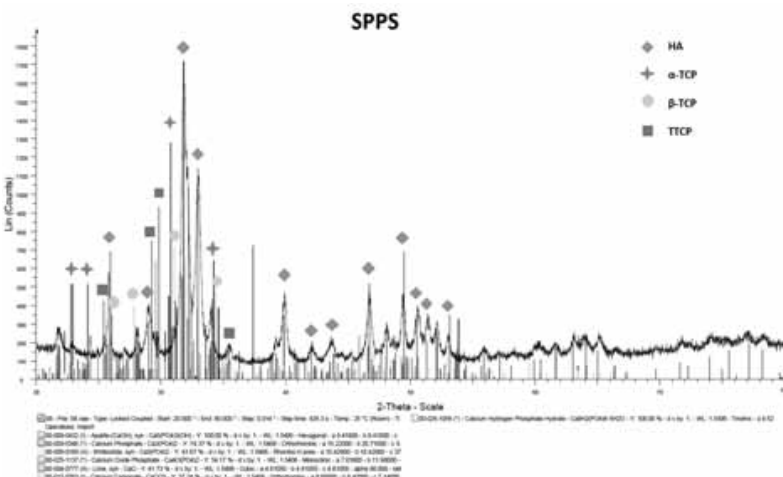

Fig. 17. Diffractogram of coating sprayed using SPPS showing characteristic peaks of $H A$

Rys. 17. Wyniki badań XRD powłok natryskiwanych metodą SPPS ukazujące typowe piki HA

\section{Conclusions}

Three different plasma spraying processes for the deposition of hydroxyapatite coatings such as APS, SPS and SPPS were performed. Microstructure and phase composition analysis of each coating enables the comparison of mentioned methods was done. Conventional plasma spray process (APS) was shown to have high coating deposition rate and uniform coating structure but owing to the large initial powder size used, large splats formation were observed and resulted to micro-cracks formation which can cause future coating failure. As an alternative to APS, SPS and SPPS coatings showed different microstructural features. Specifically, SPS sprayed HA revealed two characteristic zones: (i) dense zone corresponding to the lamellas, observed usually in thermally sprayed coatings; (ii) sintered zone containing fine hydroxyapatite grains and which correspond to the fine solids from initial suspension. SPPS sprayed HA coatings on the other hand exhibited fine-grain microstructures with the presence of spherical particles and fragmented shells as well as agglomerated particles which are characteristic features of plasma spraying using solution. Lamellas were not observed but the coating has relatively dense formation. Furthermore, phase analysis discloses that major crystalline phase present in the coatings was HA but its phases of decomposition also were present.

Future works focused on improving the deposition efficiency and reducing unwanted impurities of the SPS and SPPS sprayed HA coatings should be done in order to fully exploit the full potential of liquid plasma spraying as an alternative to the conventional powder plasma spraying.

\section{Acknowledgments}

A part of work that has been performed by Paweł Sokołowski was supported by the scholarship "Grant Plus" co-financed by the European Union as part of the European Social Fund. Rolando T. Candidato, Jr. would also like to acknowledge Region Limousin (France) for the scholarship grant provided. The contribution of the former PhD students of Prof. Lech Pawłowski, namely Rafał Tomaszek, Roman Jaworski and Andrea Cattini is thankfully acknowledged.

\section{HUMAN CAPITAL}

NATIONAL COHESION STRATEC

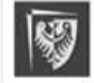

Politechnika Wrocławska

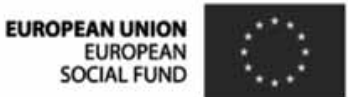

\section{References}

[1] J.R. Davis, Handbook of thermal spray technology, Pub. ASM International, Materials Park, OH, USA, 2004.

[2] L. Pawłowski, The Science and Engineering of Thermal Spray Coatings, 2nd. ed. , Wiley, Chichester, U.K., 2008.

[3] A. Cattini, D. Belluci, A. Sola, L. Pawłowski and V. Cannillo, Functional bioactive glass topcoats on hydroxyapatite coatings: Analysis of microstructure and in-vitro bioactivity, Surface \& Coatings Technology, 240 (2014), 110-117.

[4] R. A. Miller, Thermal barrier coatings for aircraft engines: history and directions, Journal of Thermal Spray Technology, 1997, Vol. 6, Issue 1, 35-42.

[5] R. Hui, Z. Wang, O. Kesler, L. Rose, J. Jankovic, S. Yick, R. Maric, D. Ghosh, Thermal plasma spraying for SOFCs: Applications, potential advantages, and challenges, Journal of Power Sources, Vol. 170, Issue $2,2007,308-323$

[6] V.Stengl, H. Ageorges, P. Ctibor and N. Murafa, Atmospheric plasma sprayed (APS) coatings of Al2O3-TiO2 system for photocatalytic application, Photochemical \& Photobiological Sciences, 2009, 8(5), 733-738.
[7] http://www.tocalo.co.jp/english/technical/aps.html.

[8] V. Deram, C. Minichiello, R.N. Vannier, A. Le Maguer, L. Pawłowski, and D. Murano, Microstructural characterizations of plasma sprayed hydroxyapatite coatings, Surface and Coatings Technology, 166 (2003), 153-159.

[9] P. Fauchais and A. Vardelle, Solution and Suspension Plasma Spraying of Nanostructure Coatings, Advanced Plasma Spray Applications, H. Jazi, Ed., In Tech, ISBN 978-953-51-0349-3, 2012, 149-188.

[10] R. Jaworski, L. Pawłowski, F. Roudet, S. Kozerski and A. Le Maguer, Influence of Suspension Plasma Spraying Process Parameters on TiO2 Coatings Microstructure, Journal of Thermal Spray Technology, 17 (2008), 73-81.

[11] S. Kozerski, L. Łatka, L. Pawłowski, F. Cernuschi, F. Petit, C. Pierlot, H. Podlesak and J. P. Laval, Preliminary study on suspension plasma sprayed $\mathrm{ZrO}_{2}+8 \mathrm{wt}$ \% Y 203 coatings, Journal of the European Ceramic Society, 31 (2011), 2089-2098.

[12] R. Tomaszek, L. Pawłowski, L. Gengembre, J. Laureyns and A.L. Maguer, Microstructure of suspension plasma sprayed multilayer coatings of hydroxyapatite and titanium oxide, Surface and Coatings Technology, 201 (2007), 7432-7440. 
[13] R. Jaworski, C. Pierlot, L. Pawłowski, M. Bigan and M. Quivirin, Synthesis and Preliminary Tests of Suspension Plasma Spraying of Fine Hydroxyapatite Powder, Journal of Thermal Spray Technology, 17 (2008), 679-684.

[14] T. Bhatia, A. Özturk, L. Xie, M. Gell, X. Ma and N. Padture, Mechanisms of ceramic coating deposition in solution-precursor plasma spray, Journal of Materials Research, 17 (2002), 2363-2372.

[15] A. Saha, S. Seal, B. Cetegen, E. Jordan, A. Özturk and S. Basu, Thermo-physical processes in cerium nitrate precursor droplets injected into high temperature plasma, Surface \& Coatings Technology, 203 (2009), 2081-2091.

[16] S. Basu, E. Jordan and B. Cetegen, Fluid mechanics and heat transfer of liquid precursor droplets injected into high-temperature plasmas, Journal of Thermal Spray Technology, 17 (2008), 60-72.

[17] E. Garcia, Z.B. Zhang, T.W. Coyle, L. Gan and R. Pillar, Hydroxyapatite Coatings Produced by Plasma Spraying of Organic Based Solution Precursor, Ceramic Engineering and Science Proceedings, Advances in Bioceramics and Biocomposites II-A Collection of Papers Presented at the 30th International Conference on Advanced Ceramics and Composites, 27 (2006), 103-110.

[18] Y. Huang, L. Song, X. Liu, Y. Xiao, Y. Wu, J. Chen, F. Wu, and Z. Gu, Hydroxyapatite coatings deposited by liquid precursor plasma spraying: controlled dense and porous microstructures and osteoblastic cell responses, Biofabrication 2 (2010), 1-10.

[19] J. D. Bronzino, The Biomedical Engineering Handbook, Second Edition, CRC Press LLC, USA and Springer-Verlag GmbH \& Co. KG, Germany, Boca Raton, 2000.

[20] A. Ragu, K. Senthilarasan and P. Sakthivel, Synthesis and characterization of nano hydroxyapatite with polyurethane nano composite, Der Chemica Sinica, 5 (2014), 124-127.

[21] M. H. Santos, M. de Oliveira, L. Palhares de Freitas Souza, H. S. Mansur, and W. L. Vasconcelos, Synthesis control and characterization of hydroxyapatite prepared by wet precipitation process, Materials Research 7 (2004) 625-630.

[22] S. W. K.Kweh, K. A. Khora, and P. Cheang, The Production and Characterisation of Hydroxyapatite (HA) Powder, Journal of Materials Processing Technologies, Vol. 89-90 (1999) $373-377$
[23] http://sciencelearn.org.nz/Contexts/Gases-and-Plasmas/Sci-Me$\mathrm{dia} /$ Images/Plasma-spray-process (2015, April 13).

[24] J. Karthikeyan, C.C. Berndt, J. Tikkanen, J.Y. Wang, A.H. King and H. Herman, Preparation of nanophase materials by thermal spray processing of liquid precursors, NanoStructured Materials, 9 (1997) 137-140.

[25] L. Pawłowski, Suspension and solution thermal spraying coatings, Surface \& Coatings Technology, 203 (2009) 2807-2829.

[26] L. Pawłowski, Finely grained nanometric and submicrometric coatings by thermal spraying: A review, Surface \&Coatings Technology, 202 (2008) 4318-4328.

[27] R. Tomaszek, Suspension plasma spraying of functional gradient coatings, PhD Thesis, ENSCL, Lille, France, 2006.

[28] www.colloidal-dynamics.com - ZetaP robe and Acousto Sizer II instruction.

[29] Malvern Instruments Ltd., Zetasizer Nano Series. User Manual, Zeta Potential theory, Worcestershire, U. K., 2003, [Brochure].

[30] A. Killinger, R. Gadow, G. Mauer, A. Guignard, R. Vassen, and D. Stover, Review of new developments in suspension and solution precursor thermal spray processes, Journal of Thermal Spray Technology, 20 (2011) 677-695.

[31] P. Fauchais, R. Etchart-Salas, V. Rat, J.F. Coudert, N. Caron, and K. Wittmann-Teneze, Parameters controlling liquid plasma spraying: solutions, sols or suspensions, Journal of Thermal Spray Technology, 17 (2008) 31-59.

[32] W. Duarte, S. Rossignol, and M. Vardelle, La2Zr2O7 (LZ) Coatings by Liquid Feedstock Plasma Spraying: The Role of Precursors, Journal of Thermal Spray Technology, Volume 23(8), 2014, 1425-1435.

[33] B. M. Cetegen and S. Basu, Review of Modeling of Liquid Precursor Droplets and Particles Injected into Plasmas and High-Velocity OxyFuel (HVOF) Flame Jets for Thermal Spray Deposition Applications, Journal of Thermal Spray Technology, Volume 18(5-6), 2009, 769-793.

[34] R. Jaworski, C. Pierlot, L. Pawłowski, M. Bigan, and M. Martel, Design of the synthesis of fine HA powder for suspension plasma spraying, Surface \& Coatings Technology 203, (2008), 2092-2097

[35] P.L. Prevey, X-ray diffraction characterization of crystallinity and phase composition in plasma sprayed hydroxyapatite coatings, Journal of Thermal Spray Technology, 9(3) (2000), 369-76. 